
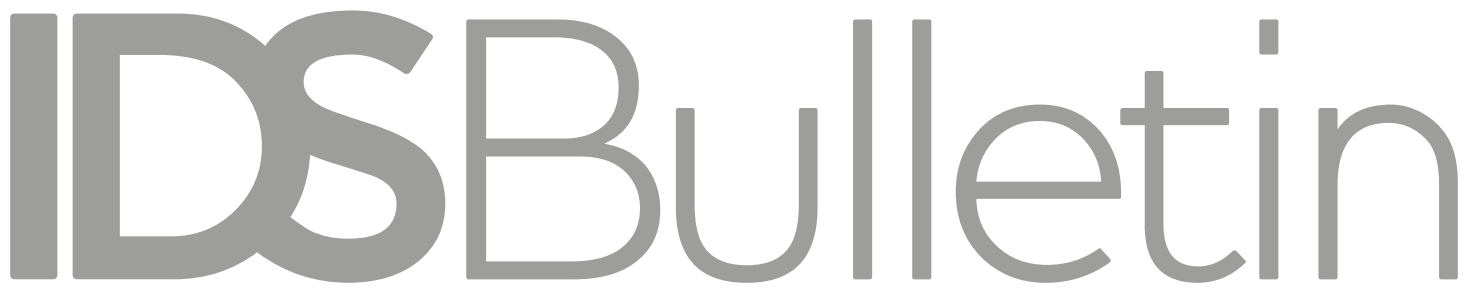

Transforming Development Knowledge

Volume 50 | Number 3 | September 2019

\title{
ACCOUNTABILITY AMIDST FRAGILITY, CONFLICT, AND VIOLENCE: LEARNING FROM RECENT CASES
}

\section{Editor Anuradha Joshi}

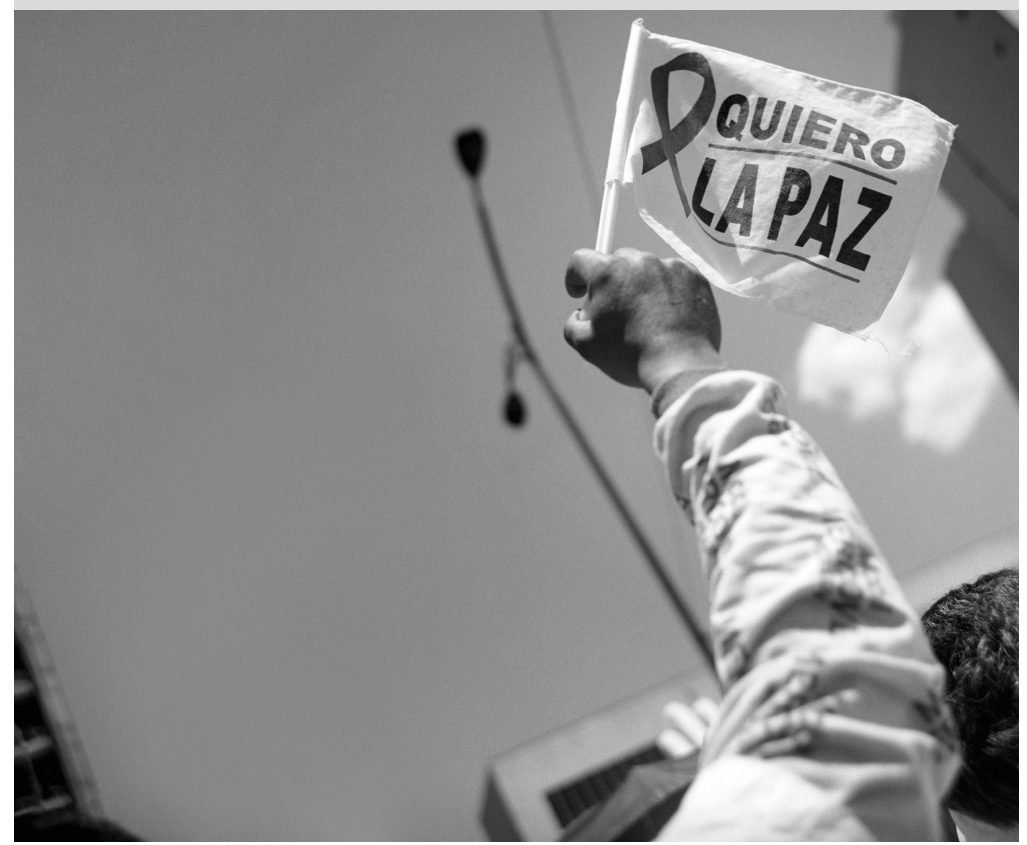


Notes on Contributors

Introduction: Accountability Amidst Fragility, Conflict, and Violence: Learning from Recent Cases

Anuradha Joshi

Myanmar's Top-Down Transition: Challenges for Civil Society

David Brenner and Sarah Schulman

Youth-Led Anti-Corruption Movement in Post-Conflict Guatemala: 'Weaving the Future'?

Walter Flores

Empowerment without Accountability? The Lawyers' Movement in Pakistan and its Aftershocks

Maryam S. Khan

Localising National Accountability Claims in Fragile Settings: The Right to Food Campaign in India

Anuradha Joshi and Aheli Chowdhury

Civilian Action in Conflict Settings: The Case of Colombia

Patricia Justino

Glossary 


\title{
Localising National Accountability Claims in Fragile Settings: The Right to Food Campaign in India* +
}

\author{
Anuradha Joshi ${ }^{1}$ and Aheli Chowdhury ${ }^{2}$
}

\begin{abstract}
How does a national movement go local in places with multiple armed actors, simultaneously retaining credibility at the grass roots, while making claims and negotiating with the state? This article explores how a rights-based movement, the Right to Food (RTF) in India, with a strong national core and some state-level support expanded into areas that were experiencing militant insurgency. We find that the RTF movement was able to coexist with the militant groups because the movement: (a) brought new framings and issues to existing groups that were already working with vulnerable populations; and (b) distinguished itself from the militant groups in terms of substantive issues and approach (avoiding issues of displacement and land rights), as it was willing to work with the state to tackle issues of hunger and food entitlements.
\end{abstract}

Keywords: India, Right to Food, grass-roots action, fragility, conflict, armed militancy, Naxalite, social movements, socioeconomic rights.

\section{Introduction}

How does a national movement go local in places with multiple armed actors, while simultaneously retaining credibility at the grass roots and making claims and negotiating with the state? This article explores how a rights-based movement, the Right to Food (RTF) in India, with a strong national core and some state-level support, expanded into areas that were experiencing militant insurgency, which was in part rooted in the lack of rights among those populations. The setting is one of subnational locations in India where the state is repressive and militarised and in which, therefore, civil and political rights are curtailed. How does the RTF movement work in these locations dominated by extremists, while retaining a commitment to achieving rights through the law? To what extent do the claims of the armed militants converge with the broader RTF movement? 
Since the 2000s, India has witnessed a wave of rights-based movements for accountability for socioeconomic rights. Starting with the National Campaign for People's Right to Information (NCPRI), many of these movements have managed to win significant gains through progressive legislation, including the Right to Information Act (RTI) 2005, Mahatma Gandhi National Rural Employment Guarantee Act (MGNREGA) 2005, the Forest Rights Act 2006, the Right to Education Act 2009, and the National Food Security Act 2013. The trajectory of these struggles often follows a common storyline: a small movement (either grass-roots-based or comprising a small organisation with middle-class activists) escalates from a relatively local struggle to a national movement which then succeeds in shifting national policy. The story of the RTI Act, starting with the efforts of the Mazdoor Kisan Shakti Sangathan (MKSS) to ensure minimum wages for workers on public works programmes in the state of Rajasthan and moving to the national level lobbying for a Right to Information Act with the newly elected Congress-led United Progressive Alliance (UPA) government, exemplifies this narrative (Pande 2014; Baviskar 2010; Singh 2010; Jenkins and Goetz 1999).

Yet, this perspective on scaling up of local struggles, while important, neglects an equally important trajectory: how do such efforts once they reach the national level, reach back to the grass roots, in locations where they have few roots, and succeed in broadening their base? Existing literature offers few clues. It has tended to focus on the operations of movements themselves, including how movements sustain over decades through high and low levels of mobilisation on the ground (Isserman 1987; Morris 1984; Tilly 1978; Whittier 1995); how interactions of organisational structures and political opportunity structures shape the continuity and character of the movement over time (Whittier 1997); and how within social movements, internal heterogeneities and subgroups of interest are suppressed in the interest of broader strategy (Sharp et al. 2000; Dwivedi 1997, 1998; Baviskar 1995). While these studies highlight essential aspects of movement dynamics and operations, there is less attention on understanding how movements sustain their presence on the ground, particularly in settings of fragility, conflict, and violence. Baviskar's (1997) work on Narmada Bachao Andolan (NBA) that operated in a similar terrain to the RTF movement reveals the complex relationship of the tribal groups with nature, the state, and the co-habiting middle-class activists, but does not shed much light on how the movement negotiated space within settings of conflict and violence.

This article focuses on this less studied dynamic - of the downward diffusion of social movements - drawing upon the experience of the RTF campaign in India in three states affected by left-wing extremism (LWE). ${ }^{3}$ The evolution of the well-known RTF campaign in India is a good case to explore these questions. The campaign originated with a Supreme Court Case, in which a human rights group - the People's Union for Civil Liberties (PUCL) - charged the government with 
inaction in preventing deaths through starvation while there was surplus food rotting in government storage silos (Birchfield and Corsi 2010). The campaign gathered some credibility and momentum through the interventions of the Supreme Court in the form of orders that mandated the government to take immediate action to prevent any form of starvation and hunger and to consider it as their (central and state) primary responsibility.

The Supreme Court appointed 'Commissioners' to monitor implementation of all orders relating to the case. The orders of the court then became a rallying point around which activists and groups in different states came together to form the RTF campaign. The campaign remained a loose network of groups and individuals who provided ground-level information about implementation of the court orders to the Office of the Commissioners. The story of the evolution of the campaign from this small beginning to the passing of the National Food Security Act in 2013 has been already documented to some extent and will only be touched on lightly here (Hertel 2015; Srinivasan and Narayanan 2007).

What is often less stressed is that the RTF campaign, supported by the Supreme Court orders, has been extensively animated by unrelenting national-level advocacy by the Supreme Court Office of the Commissioners in New Delhi. Simultaneously, the same office, in coordination with the RTF campaign, has made a concerted effort to foreground issues of food entitlements to civil society groups at the subnational level. ${ }^{4}$ The Office of the Commissioners at the subnational level worked in tandem with RTF campaign members, in monitoring the implementation of the Supreme Court orders in the states. They played a key role in the investigation of deaths through starvation, mobilising awareness of relevant orders (prior to the act passing), establishing monitoring mechanisms such as public hearings, and linking groups to national-level action. Yet, this subnational story has been less explored, particularly of how the state-level RTF campaign mobilised and linked local groups to the national campaign. Of particular interest, and so far undocumented, is how this process unfolded in states such as Chhattisgarh, Jharkhand, West Bengal, Bihar, and Andhra Pradesh, which are dominated by large tribal populations and are substantially affected by violent conflict due to the presence of Maoist-inspired LWE groups.

It is only recently that the literature has been engaging with issues of how rights-oriented court judgments are complied with (or not) and the role of social movements within them (Langford, RodríguezGaravito and Rossi 2017). Assessing a number of cases, they conclude that, 'particularly important appears to be the degree and extent of internal mobilisation amongst litigants, the strength of leadership in affected communities and the types of alliances in the enforcement phase' (ibid.: 25). Simultaneously, the literature on the role of law in social change acknowledges that favourable judgments might not be enforceable. 
Social movements view the courts as only one of the many arenas within which struggles occur (Hunt 1993; Joshi 2010). The hope is that legal judgments shape the way issues are conceived and discussed both by the aggrieved parties as well as the broader public (McCann 1994).

In addition, judgments provide protection for social mobilisation 'being on the right side of the law'. As Rohit De (2018) shows in his recent book on the cases brought under the Constitution immediately post-independence, even when the court failed to uphold rights, activism was still important in shaping the law, as well as the range of other actions that organised groups took against the state. Thus, courts in practice offer both: a remedy for the rights violations as well as cover for social mobilisation. Viewed in this manner, the RTF campaign's spread into conflict-affected states is natural, but also poses an additional challenge for such accountability work in fragile settings: how does a movement navigate the terrain with multiple armed actors, retain credibility at the grass roots, and simultaneously make claims and negotiate with the state without appearing threatening?

Based on interviews with state- and national-level RTF activists in three such states, ${ }^{5}$ this article offers insights into how social movements manage alliances and garner support, in contexts of violent conflict and the presence of alternative groups (sometimes armed), with different ideologies that might equally draw support from, and are embedded in, local communities. Three key features of such downward diffusion stand out. First, not surprisingly, when entering new and particularly fragile, complex terrain, the experience of the RTF shows that they have to focus efforts on reorienting existing groups towards food, rather than attempting to start new groups from scratch. Second, the RTF, like many movements, attempts to balance a confrontational stance towards government, with an engaged, cooperative stance as a strategy for increased effectiveness. The RTF is seen as a group that clearly has state allegiance and works within the framework of the Constitution to hold the state accountable. In the contexts of conflict, however, this becomes imperative for avoiding being targeted as a terror-supporting organisation.

Simultaneously though, such balancing puts credibility with the local populations under constant jeopardy. In the recent past, there has been an increasing incidence of mass-scale displacement and suppression of the dissenting population in these states. This has further intensified the crisis within the local population and how they view the state. Paradoxically though, as we show, it is this 'working with the state', which seems to have been the reason why the RTF has managed to work in areas with LWE presence. Finally, the case shows that despite an initial separation of issue areas related to food and livelihoods security, both the RTF campaign and the LWE are evolving towards similar positions on key issues - a fact that is not surprising given that both are seeking legitimacy for their work from local populations whose primary need is material and social wellbeing. 
The article is laid out in the following way. Sections 2 and 3 provide some background to the RTF campaign and the Naxalite movement in India. This is followed by two substantive sections that present the interview findings - Section 4 details how the RTF campaign operated within these states and Section 5 shows why they were able to coexist peacefully with the LWE groups. Section 6 concludes.

\section{The Right to Food campaign}

The RTF campaign is usually considered to have started with the Civil Writ Petition 196/2001, filed by the PUCL against the Union of India and others. The core contention was that the government had not acted to prevent deaths through starvation in the country despite holding a large stock of food grains under the Public Distribution Scheme (PDS), which was aimed at food security for the poor through the provision of subsidised food grains. The case, popularly known as the 'Right to Food' case, was soon to become the longest running mandamus on the right to food in the world (see Figure 1). The Supreme Court, through two key steps was instrumental in shaping the trajectory of the RTF campaign in the country (Sinha et al. 2014).

First, it passed close to 200 interim orders in the case, requiring the government to undertake action on a range of food-related issues, including school midday meals, supplementary nutrition for pregnant and lactating mothers, the food subsidy scheme, pensions, and maternity benefits. These orders converted government programmes into legal entitlements. Second, it created a Supreme Court Office of the Commissioners, and appointed two Commissioners - N.C. Saxena and S.R. Sankaran (who was later replaced by Harsh Mander) ex-government bureaucrats, to monitor the implementation of the interim orders in the states. The Commissioners were sympathetic to framing food as a right and attracted staff who were either drawn from food-related civil society groups, or sympathetic to them - to the extent that the Office of the Commissioners was deeply allied with the RTF campaign. Many of the state-level advisors of the Commission were simultaneously part of local activism and played the dual role of monitoring as well advocacy.

This consequential RTF case and related campaign had its origins in the prevalence of hunger and starvation deaths in the state of Rajasthan where the PUCL chapter had been the node for a network of civil society organisations (including MKSS, which was the grass-roots organisation at the heart of the RTI movement). The initial shoots of the campaign found support in progressive human rights lawyers including Colin Gonzalves and journalists such as P. Sainath, who highlighted the paradox of 'hunger amidst plenty' and reformist bureaucrats such as B.N. Yugandhar, Abhijit Sen, and Syeda Hamid at the Planning Commission. The campaign quickly morphed into a loosely knit, non-funded, decentralised network of grass-roots groups and activists united in their commitment to the 'realisation of the right to food in India' ${ }^{6}$ Most of these grass-roots groups in the states were part of other networks such as the 
Figure 1 The Right to Food campaign, India

Writ Petition submitted to the Supreme Court of India by the People's Union of Civil Liberties, Rajasthan. The case thereafter known as the PUCL vs Union of India and others, Writ Petition 196 of 2001. The petition asks the court to order the Government of Rajasthan to (a) provide immediate open-ended employment in drought-affected villages, (b) provide 'gratuitous relief' to persons unable to work, (c) raise the Public Distribution Scheme (PDS) entitlement per family, and (d) provide subsidised food grain to all families. Finally, the petition requests the court to order the central government to supply free food grain for these programmes.

\section{April 2002: Day of action on Mid-Day Meal} Instrumental in persuading several state governments to initiate cooked midday meals in primary schools.

Six National Conventions $(\boldsymbol{\Delta})$ on food-related issues held to date. These conventions discussed issues, took stock of the implementation of the Supreme Court Orders at

the subnational level, and also planned future action.

May-June 2005: Rozgar Adhikar Yatra ( 1$)$, a 50-day tour of India's poorest districts to demand for immediate enactment of the MGNREGA.

September: At a day-long convention in Delhi, the Right to Food campaign drafted a set of common 'essential demands' for the National Food Security Act.

Based on this, the campaign formulates the draft Right to Food Act.

September: The Government of India passed the National Food Security Act, 2013.

February: The Supreme Court closes the Right to Food case.

\section{1}

As an offshoot of the Supreme Court case, the Right to Food campaign is formed.

\section{2}

The Supreme Court through interim orders appoints Dr N.C. Saxena and Mr S.R. Shankaran as 'Commissioners' for the purpose of monitoring the implementation of all orders relating to the Right to Food case.

Subsequently, a subnational Office of the Commissioners was set up with advisors to assist the national Commissioners in monitoring implementation.

\section{3}

Bhopal, June 2004

\section{5}

Responding to the long-standing demand of the campaign, the government passed the MGNREGA. It was passed in 2005, but implemented from February 2006 onwards

Kolkata, November 2005

2007

Bodhgaya, April 2007

2009

Rourkhela, August 2010

2013

Gujarat, April 2014

2017

Ranchi, September 2017

Present 
National Alliance for People's Movements and the RTI campaign, and worked on issues of land and displacement, health, education, and others.

Given the salience of the RTF case, the sweeping orders being issued by the Supreme Court, the formation of the Supreme Court Office of the Commissioners, and the significance of the media in placing the issues on the national agenda, the RTF campaign very soon became more active at the national level advocating for a Right to Food Act. Between 2009 and 2013 when the idea of passing a food security act was being drafted, the campaign focused its energies on influencing the contents of the proposed act, consulting heavily with its membership, and was fairly influential in shaping the final draft. ${ }^{7}$ The National Food Security Act was finally passed in 2013 by the Congress-led UPA government. It was one of the last rights-based laws to be passed by the UPA before it fell from power in the 2014 elections.

This is not to say that grass-roots campaign work in the states was not ongoing; just that it was not as much in the limelight at the time. The campaign and affiliated organisations at the state level launched awareness-raising activities, social audits, protest marches, and held at least 16 high-level conventions on the right to food or related issues over a period of 14 years. ${ }^{8}$ What is less appreciated is the issue of how the RTF campaign managed to work in states such as Bihar, West Bengal, Jharkhand, Chhattisgarh, Orissa, Andhra Pradesh, and Maharashtra where it did not have a strong presence on the ground initially and which had several districts with a heavy presence of LWE groups. In these states, high levels of poverty, large tribal and schedule caste populations combine with an inhospitable terrain of forest and hills, making these locations well suited for guerrilla tactics, and particularly inhospitable to mainstream civil society movements. We turn to the origins and ideology of these LWE groups next.

\section{The Naxalite movement and marginalised groups}

The 'Naxalite' movement has its roots in Naxalbari, in north Bengal, where in 1967 a peasant uprising broke out with the support of the Communist Party of India (Marxist) (CPI-Marxist). Three veteran leaders of the party - Charu Mazumdar, Kanu Sanyal, and Jangal Santhal - had been mobilising the peasants against oppression by the landlords. Peasants forcibly occupied land, burnt land records, and looted property, establishing a stronghold in the region. The government reacted by sending police to crush the movement, with the police opening fire, resulting in the death of nine villagers. These actions by the government were widely criticised and had wide-reaching impacts in terms of triggering similar movements across the tribaldominated states nearby. Since then, the Naxalite movement, drawing upon Maoist ideology, continues to affect several states in India where the LWE groups have established guerrilla bases. In 2006, more than 60 districts across ten states were affected by LWE. By 2009, the Naxalites were influential across approximately 180 districts in ten states of India (Giri 2009; Planning Commission 2008). 
The basic driver of LWE was the failure of the state to implement the Fifth and Ninth Schedules of the Constitution of India which call for autonomous self-governance and land reforms. ${ }^{9}$ No state has so far implemented the Fifth Schedule, and only three states have implemented land reforms - West Bengal, Jammu and Kashmir, and Kerala - and even in these, the reforms have been incomplete. This lack of implementation led to the rise of the Naxalite movement supported by local tribal and marginalised populations. The core challenge is that of feudalism, and the aim of the movement is to overthrow landlords and regain control of natural resources (land, forests), which are the primary source of livelihoods for the tribal populations. In this, the LWEs contrast with more mainstream left parties which view the main challenge to be that of the economy with its colonial roots, and integration into the system of global capitalism. As Prasad notes,

The nature of left politics in India has been structured by this difference in interpretation, while Naxalites and Maoists have preferred to interpret the power structure in rural India as semi-feudal, the nature of capitalist relations in agriculture and allied sectors had remained the focus of other left parties. Therefore it is not surprising that the growth of the Maoist movement has been far greater in places that have not experienced either land reforms or high agricultural growth (Prasad 2010: 7).

These struggles have taken different forms in the different states affected by LWE. In Bihar, there are two streams within the movement: the CPI (Marxist-Leninist) (CPI ML) Liberation which is considered 'revisionist' by the other Naxalites; and the amalgamation of the CPI (ML)-People's War and the Maoist Communist Centre, in 2004 to form a new party, the CPI (Maoist), also known as CPI (M). ${ }^{10}$ The core support in Bihar has tended to be from landless agricultural labourers or poor peasants, often from the lowest castes (Bhatia 2005). In Chhattisgarh, the expansion of the Maoists was the result of the formation and influence of the People's War Group in Andhra Pradesh, which started operating in the Dandakaranya region in the district of Bastar that borders Andhra Pradesh. In the 1990s, they formed two organisations, the Dandakaranya Adivasi Kisan Mazdoor Sangathana (DAKMS) and the Krantikari Mahila Adivasi Sangathana (KMAS).

Prasad (2010) notes that although the Maoists gained support by focusing on issues of daily importance, their practices lasted only until they gained control, after which they ruled through coercion and ruthless elimination of opposition. In Jharkhand, the main group, the Maoist Communist Centre (MCC), appears to have mobilised support through running a protection racket for the rural elite, offering protection to the resources of the state, as well as protection from its own excesses, rather than being a poor people's movement (Shah 2006). The presence of the Maoists in Odisha has declined in recent years, with no activity in five districts. ${ }^{11}$ In other districts, the groups that are active apart from the CPI $(\mathbf{M})$ are the breakaway 
Odisha Maobadi Party (OMP), and People's Liberation Front of India (PLFI). In West Bengal, where grass-roots politics has been well embedded in society, LWE groups are many, with the dominant one being CPI (M), and often the boundaries between grass-roots movements and LWE are blurred.

In addition, a generational shift is emerging in tribal areas of all states: increasingly the younger generation of tribals and landless labourers no longer want to continue farming or depending upon forests for livelihoods, and challenge old customs (deference to elders, marriage laws, etc.) (Shah 2011). Such youth are joining LWE groups, where they can get a taste of power gained by direct action of looting from landlords, moneylenders, or state-subsidised fair price shops (Ramana 2008; Thivet 2014). These similarities and variations in the nature of LWE shape the nature of interactions with the RTF and the potential for it to grow deep roots in each state.

The Indian state, for its part, has oscillated between defining the Maoist movement as a 'law and order' problem and as a socioeconomic problem. In its 'law and order' framing, the state uses the repressive weight of the security forces to address Maoist-led insurgency. In its socioeconomic problem framing, Giri (2009: 465) argues that the state has defined the Maoists through three lenses over time - first as the byproduct of the failure of the 'development model' of the state; second as fighting for the rights of the poor and marginalised; and last, recognising them as an alternative political formation inspired by the need to find common ground between LWE groups and the state agencies. ${ }^{12}$

This latter reading of the state's view echoes with the view of the left. The Indian left has argued that the government has long used the 'Maoist threat' to justify the rise of the security-centric state. The Indian left continues to critique the repressive capitalistic neoliberal state, but their position is one of accommodation within a democratic framing. Giri (2009) argues that this understanding of the Maoist movement by the Indian state and the Indian left shifts the discourse, from it being a security problem to it being a socioeconomic issue, which can be resolved by better state intervention. This clearly serves to 'exclude them [the Naxalites] out' as a political alternative (ibid.: 463). Thus, as we will see, not only are there differences between the positions of different factions within the Naxalite movement, but there are a multitude of positions towards them from the Indian state and from those on the Indian left, that coexist and shape the contested terrain of Indian politics.

\section{Taking the campaign to the states}

The RTF campaign faced several challenges in reaching out to states where there was a significant Naxalite presence. First, these were states where a comprehensive platform of food-related issues had not been on the agenda for development practitioners. Existing groups focused often on only part of the problem; for example, groups working on child rights which took on midday meal issues, or groups working on 
transparency which looked at corruption within the PDS. Further, in these states, issues of tribal rights to land and forests loomed large and were the issues around which the many groups mobilised. The challenge then, was to bring various activists together under a comprehensive 'right to food' framing.

Second, substantial parts of these states were affected by conflict due to the use of violent tactics by the LWEs, making it more difficult for the work of the RTF oriented to peaceful rights claims. The uneven presence of the state and state programmes, the multiplicity and ambiguity of different groups, and the challenges of establishing credibility with the local populations were hurdles that the RTF campaign had to overcome.

Third, in these settings, the state already had an extremely distrustful view of civil society organisations, viewing them as thinly disguised terrorist organisations. As we shall see, any criticism of the state, or demands for accountability, made the RTF campaign vulnerable to being labelled as LWEs. Finally, these locations were among the poorest states in India, which meant that although they were the ones with the greatest need, they were also those with the most limited capacity and resources for full implementation of the right to food, even if they were politically committed to doing so. Evidence from our interviews, recounted below, presents an account of how the RTF campaign navigated this shifting and uncertain terrain.

\subsection{Linking with grass-roots groups}

In the early 2000s, bringing the RTF movement to the local level in the conflict-affected areas revolved around forging links with existing groups. In one state, people who had been involved with literacy issues joined the RTF campaign. In another, the focus of one group had been on dalit rights. The coalitions at state level thus included a range of issues such as health care, violence against women, forest rights, maternal and childcare, or agricultural workers. These groups came together because the RTF campaign offered something for everyone, an overlap with their issues of concern. In the three states we examined, the RTF campaign usually started with a small set of core organisations that led the work in the state.

Initially, many groups in the state-level campaigns were funded by international non-governmental organisations (INGOs). ${ }^{13}$ Yet, over the years, with shrinking space for social activism, it was precarious to accept INGO funding, and simultaneously INGOs retreated from support of overt challenges to the state. As one activist noted: 'At the time it was fine by these funded organisations to work on rights-based issues, but now they have become scared'. ${ }^{14}$ Some even viewed INGOs with suspicion: 'We have had funding agencies wanting to blatantly break the campaign. It was always a non-funded campaign'. ${ }^{15}$

From early on, the preference was to work with existing grass-roots groups which were working on some part of the right to food agenda. 
As an activist noted,

We focused particularly on organisations that have a mass base. This is because we think that this is not NGO-type work. The moment you involve NGOs then the spirit is gone. The $\mathcal{N} G O$ s are always very worried about their future, about projects, FCRA [Foreign Contribution Regulation Act] cancellation. They also tend to do only awareness and mobilisation, and mostly avoid doing active struggle. ${ }^{16}$

This sentiment was echoed by another interviewee:

For us, also we feel it is better that we move away from funded organisations to include individuals and people who directly want to work with us... Basically we are now moving from being an $\mathcal{N G O}$-based campaign to become a more people/mass-based campaign. ${ }^{17}$

In India, the 1980s saw the advent of NGOs, with the central government recognising their role as a delivery agency for rural development. They mushroomed over the next two decades and have been distinct from large social and peoples' movements. They have been funded and staffed with professionals, in contrast to the social movements, which have remained non-funded and based at the grass roots. NGOs have over time supported and also participated in social movements, but were viewed mostly as outsiders. The general perception has been that NGOs are less radical, less critical of the state, and prone to taking decisions based on funding needs (Raina 2004).

This tension persisted and intensified after the amendments to the FCRA in 2010 which prohibited NGOs receiving foreign donations from undertaking 'anti-state' activities. Reflecting this mix of NGOs and movements and in contrast to popular perception, the RTF campaign's grass-roots origins in these states were uneven and varied from state to state. National activists invested significantly in reaching out to local groups - both social movements and NGOs - to activate them around issues of food. Yet, these efforts were circumscribed by the presence of the LWE groups in the state, an issue we turn to next.

\subsection{Presence of left-wing extremism}

The scale and extent of left-wing extremist activity varies from state to state, and for the most part LWE groups are present only in some blocks/districts of the state, while RTF campaign work is more widespread. By and large, LWE groups did not counter the growing influence of the RTF campaign as it expanded, as Chandra points out in the case of Jharkhand: 'Non-governmental organizations are rarely, if ever, stopped from working for grass-roots development' (Chandra 2013: 57). Rather, LWE groups often remained unseen and the RTF campaigns coexisted somewhat uneasily, aware of their presence. In one state, an RTF activist noted, 'The presence of these groups (Maoists) is invisible by and large. The main activities of these groups are concerned with the security forces'. ${ }^{18}$ Yet the same activist noted that in some 
pockets, 'The entire area is under the control of the Maoists. In these areas, there is no presence of [the] RTF campaign, and I don't think that they would be allowed either'. ${ }^{19}$ In state $\mathrm{Y}$, a state with tracts of forested areas completely under LWE control, our interviewee stated that,

The core RTF and the core violence of those two areas are very different. The reason being that initially again, the presence of civil society groups in those [the LWE] areas was very thin. And those that were there, were pushed out by the state. It was not feasible for activist groups to remain active there on any issue. ${ }^{20}$

And yet, he noted, 'For the RTF this has been a sore point, that there was never a feasible strategy of how to cover those areas'. ${ }^{21}$ In state $\mathrm{X}$ by contrast, the RTF worked 'more or less everywhere or rather anywhere'. ${ }^{22}$

Several activists challenge the narrative of widespread LWE-led terror and believe that the state was using the presence of LWE as an excuse to repress populations and censor civil society groups. One interviewee observed that the government was deliberately exaggerating the presence of LWEs for its own ends. 'We are in the block that is considered to be Naxal affected, but we have not seen their presence that much. We feel that it is a myth, a myth that has been created to terrorise the area. It's a myth created by the state'. ${ }^{23}$ In state Y, our interviewee noted that, 'On paper a lot of the districts are classified as LWE... But actually, the violence-affected areas are very small'. ${ }^{24}$ Another pointed out that,

Certain parts of the state have the presence of Naxalite groups, but these groups too are also forced to take a line supporting the people's demands, apart from their own agenda of armed struggle. Unfortunately, the state has a myopic view that treats every resistance by people and every civil society criticism as 'Maoist' influenced, and tries to tackle these with military repression. This leaves very little space for civil society work. ${ }^{25}$

Making the same point, another noted, 'If you do activism, you can be branded a Naxal. It is a convenient excuse for the state to come down on any form of activism'. ${ }^{26}$ Depending upon who is being pilloried, an activist from state $\mathrm{Z}$ noted, 'They [the government] at times call me the NGO-wala, and at other times they call me Maoist'. ${ }^{27}$ Overall, activists felt that the presence of Naxals was reducing the space for any movement on socioeconomic rights.

The RTF reaction to such labelling by the state was hard-hitting. When an RTF activist was implicated in an incident of violence and branded a Naxal, the campaign took an assertive stand denying any links with the LWE. 'We went aggressive, because we felt that if we didn't put our foot down now, we would be dragged into all kinds of activities that Maoists were involved in'. ${ }^{2}$ In another state, the RTF was proactive in addressing the challenge of the LWE, which proved to be a successful strategy for carving out an independent space. 
The RTF reached out to the Maoist groups. They published pamphlets with clear messages which communicated with the Maoist groups by saying that 'they' need to address basic and essential issues of people. They cannot expect the most deprived to be part of a movement to overthrow the state when they are struggling to get one square meal for their families. After the campaign, the Maoist groups also started respecting the work of the RTF and since then they have never interfered. ${ }^{29}$

Yet others observe that LWE groups also have occasionally taken up issues of raising minimum wages and implementation of the MGNREGA (Chandra 2013).

The challenge, though, for the RTF campaign is that, on the ground, the lines between various factions of the LWE groups, civil society organisations, and grass-roots movements are rather blurred. In an environment where the local state is weak and possibly captured, alliances and adversaries are fluid and changing:

In $[\mathrm{X}]$ state, there is a general problem of criminalisation, corruption, and extreme backwardness... Sometimes there is some sort of a nexus between the Maoists, pseudo-Maoists, anti-maoists, police-sponsored gangs, and all kinds of factions. Basically, in these areas, democratic institutions are not functioning, and that makes the situation worse. ${ }^{30}$

\section{Competition or coexistence?}

The presence of LWE in areas where the RTF campaign is increasingly active raises the question of whether the groups compete for the support of the local population, and how the LWE groups view the work of the RTF campaign and vice versa. As highlighted earlier, for the most part, they seem to be operating independently, sometimes in the same locations. Two factors seem to maintain this separation: on the one side, the perspective of the LWE groups on working with state institutions and programmes such as the PDS, and on the other side, the relative lower priority for the RTF campaign regarding raising issues of land rights, though in some states they are raising issues of forest rights.

As others have pointed out, in contrast to mainstream communist groups that have focused on rights over natural resources and to minimum wages as a step towards Indian socialism, LWE groups view the primary power structures in rural India as semi-feudal, with the Indian state continuing the feudal traditions of the colonial state (Prasad 2010). Thus, LWE groups are against the state itself, rather than attempting to make the state responsive. Similarly, rather than critique capitalism and neoliberal policies, LWE groups are not 'against the intrusion of the market', a point illustrated by their position on the issue of forest produce such as tendu patta which was nationalised by the government with set prices (ibid.: 13). Their struggle was to denationalise, and force middlemen in the market to pay reasonable prices. 
These positions are unsurprisingly instrumental. As Prasad notes, 'The attitude of the "Maoists" towards traders and contractors was guided by meeting the short-term interests of the tribal people in order to organize them in their support' (ibid:: 13). The LWE strategy of supporting their own cadres is based on divisions between the chhapparmar zone (raiding zone) and the 'liberated' areas where they are in full control. The main source of income is by imposing informal taxation (rangdari) on people and natural resources in the raiding zone (Prasad 2010; Chandra 2013). Such organisation of LWE groups goes some way in explaining their attitudes to the RTF campaign.

Thus, for the most part, the RTF campaign has found little interference in their work, as basic needs of the marginalised, such as food, cannot be opposed without invoking the antagonism of local populations. To illustrate, one activist pointed out,

They don't think much of these schemes [food entitlement programmes]. But they wouldn't undermine it either. They know that food is important for people. So if that's the case, then their presence makes no difference to us. They don't interfere with the RTF campaign either. The RTF campaign works in many areas which has presence of Maoist groups. ${ }^{31}$

Foremost, the lack of interest also stems from their political position. LWE groups do not want to back or improve any initiatives taken by the government for food security. One RTF activist noted,

They think of us as reformists who are talking nonsense... they think of the RTF as some NGO initiative that negotiates with the government for things. That is their biggest contention with us, the fact that we are constantly negotiating with the government. ${ }^{32}$

Some view such a position as having lost them some support:

It is a bit of their lack of thinking. If they would have supported MGNREGA and opposed criminal siphoning of money, they would have gained a lot of ground support. But for them, anything that is within the system is not worth it. ${ }^{33}$

Instead we were told, 'The Maoists, the party, does not interfere with these schemes and programmes. They take money from the contractors and vendors, so far as I know they would not interfere with the PDS or MGNREGA'. ${ }^{34}$

Yet, on occasion, the two sides have worked on the same issues, albeit not together:

The left groups are also acknowledging the need to address basic people's issue. Say, when the hunger deaths happened, we responded. These incidents have made them realise that people need food and they can't keep waiting for revolution on empty stomach. They are also engaging on these issues. ${ }^{35}$ 
In another state, 'The Maoist groups have tacitly supported our work. For instance, during the hunger death incidents, the Maoist groups also worked to supply food grains in the village; before this they would mostly remain ignorant to such incidents' ${ }^{36}$

Beyond non-interference with groups working on basic needs such as the RTF, LWE groups also surprisingly found that the RTF movement did not intrude on a core issue that they were advancing, that of land rights. Such a position from the RTF movement, particularly in these states, needs some explanation. Although the issue of land rights (and related forest rights) and reforms underpin food security and have always been on the broader agenda of the RTF movement, with the exception of a few groups they have not been taken up actively. ${ }^{37}$

One reason for this was that the RTF movement originated from the PUCL case and the orders that flowed from that, and the broadening of the campaign issues only occurred later. A related possibility, one that we could not confirm, was that the RTF movement, through the PUCL case, was engaging with the state around resources it already had, whereas the issue of land rights and natural resources run up against powerful private and political interests, and therefore lack political champions. Yet another reason was that, as discussed earlier, civil society groups in these states are viewed with suspicion, and any group that called for land rights could be dubbed terrorists and their work would be hindered. As an activist noted,

The RTF has moved from agitation to strategic intervention, where they oppose the government a lot more on paper, but also work with them and make alliances with them strategically to improve the implementation of different schemes... The confrontational mode limits the degree of intervention. ${ }^{38}$

Or as another activist from another state put it:

RTF has maintained a strategic relationship with the government. They work hand in hand with the state and infuence policy matters. Therefore, as a strategy they often avoid getting into an overtly conflicting situation with the state... as they have been able to acquire space to work within the system, they would rather not compromise the space. ${ }^{39}$

Yet, in state $\mathrm{Y}$, there was some disagreement on this from one of our interviewees. He noted, 'The areas of land rights and the areas of Naxals, those are also very different' ${ }^{40}$ The argument was that in that state, the tribals were not being displaced from their lands, there was no mining happening there - it was in other locations that the land issues were salient, yet those were not LWE-dominated.

Although the collective statement of the RTF campaign does state the importance of land, it could have greater emphasis. Some activists saw it as a missed opportunity:

Criticism has always been there from left groups as well as groups working on displacements and land right issues. They always tell us that we revolve around 
the government and on schemes and subsidies. We do little to question larger issues of inequality and inequity, issues of land and displacement. But we are also moving towards that. We feel that it is needed to address these issues, but there is need to address basic needs of people like food and ration. We are thus moving from the food security to food sovereignty. ${ }^{41}$

I think, we as the campaign have failed to make these connections. The connections between dispossessions and people's claims on local natural resources on the one hand and the demand for entitlement of say, food and employment on the other. I think the main reason is that in the case of displacement movements, the state is seen as the enemy, it is in fact the enemy, but that is not the only role that the state plays. It also plays a constructive role. When we are making claims on the state, the assumption is that the state is in a constructive role. I think there is no tension in seeing that the state has on the one hand a repressive role and on the other hand a constructive role. But for most people, it's one or the other. That is the tension and the gap that we have not been able to address. But it can be done. ${ }^{42}$

Since the election of 2014, with a massive Bharatiya Janata Party $(\mathrm{BJP})$ victory at the national level, there has been a shift in the political environment, with a government that is friendly to business groups and which views conventional civil society as threatening. The subnational level too has seen changes of government, which combined with the reluctance of the central government to support rights, has meant that RTF campaigns in these states have lost valuable allies. These allies until then had enabled them to collaborate and at the same time advocate and demand accountability. Since 2014, there has been a shift from the previous government's support for rights-based legislations and schemes that they had introduced. Though instances of land acquisition and mass-scale displacement had begun post-1990s, the biggest displacement struggle ${ }^{43}$ due to the Sardar Saravor Dam has intensified in the last five years. Coupled with threats of targeting and surveillance by the government on members of civil society participating in so-called 'anti-state' activities, this lack of support for rights-based approaches has further led to shrinking democratic space (Chandhoke 2017). As a result, the RTF campaigns in the states are working on smaller issues that can sustain the momentum of the campaign, while not invoking the wrath of the state. Strategies have shifted:

There are softer forms of action, writing to the collector, organising a meeting. We avoid such actions, such as sitting on hunger strike, it gets noticed by media... it is more confrontational... so, do smaller forms that are viewed as less threatening. ${ }^{44}$

In such a context, the presence of LWE has seriously reduced the space for any action, and the outlook for further expansion of rights-based work is poor.

\section{Conclusions}

This article has traced how a relatively successful national campaign on the Right to Food reached back to mobilise support at the grass roots 
in new locations; particularly those affected by fragility, conflict, and violence. The process, as we saw, involved a meeting in the middle, where the RTF brought new framings and issues to existing groups that were already working with vulnerable populations. The ability of the newly formed networks around food at the state level to mobilise support, however, depended upon the reaction of the armed groups to such work. In the case of the LWE-affected states in India, they coexist without infringing on the spaces being occupied by the other.

The perception of the state towards LWE serves to enable their coexistence. LWE groups are seen by the state simultaneously as benevolent actors striving to bring justice to the people most marginalised by the neoliberal state, while at the same time as a security threat due to the 'means' that they use. This perception, and the strategy of the RTF campaign to work with the state, provides both RTF and LWE ideological common ground to coexist and cooperate in delivering rights and entitlements to a marginalised population rather than being in conflict with each other.

Moreover, the passage of the National Food Security Act in 2013, and the change of government in 2014 has further complicated the contested political field between the democratic state, the Maoist movements, and the RTF campaign in India. For the RTF movement, it has sharpened the focus of its campaigns at the state level, as there is a greater role for monitoring the implementation of the act and ensuring better access for the people to its entitlements. However, with the overall shift to a hostile political environment for civil society groups carrying out accountability work since the election of the BJP government in 2014, both LWE groups as well as civil society have had to rethink their strategies. How the new dynamics will play out in the long run remains to be seen.

\section{Notes}

* This issue of the IDS Bulletin was prepared as part of Action for Empowerment and Accountability (A4EA), an international research programme exploring social and political action in fragile, conflict, and violent settings. A4EA is a consortium led by IDS and funded with UK aid from the UK government. The views expressed do not necessarily reflect the official policies of our funder.

+ We would like to thank our interviewees for trusting in us and giving generously of their time despite the challenges they might face for doing so. For obvious reasons, they shall remain anonymous. We are also grateful to Jean Drèze, Jonathan Fox, Naomi Hossain, Biraj Patnaik, and Dipa Sinha for very useful comments on an earlier version of this article, and to Stephanie Lenz for designing Figure 1.

1 Anuradha Joshi, Research Fellow, Institute of Development Studies, UK.

2 Aheli Chowdhury, Independent Consultant.

3 In this article we use the term left-wing extremism (LWE) or left-wing extremist groups (LWE groups), Maoists, or Naxals interchangeably, 
to indicate a large number of organisations inspired by Maoist ideology, and whose primary aim was to foster revolution against state structures. These groups are colloquially called Naxalites. All forms of Naxalite organisations have been deemed terrorist organisations under Indian law.

4 Exceptions include the short section devoted to this by Birchfield and Corsi (2010: 723); Krishnan and Subramaniam (2014); and more recently Pande and Houtzager (2016).

5 We carried out interviews with national- and state-level activists of the RTF campaign between late 2017 and early 2018. The names of the interviewees as well as the names of the states have been anonymised for protection of the interviewees. For obvious reasons, we did not interview people from the LWE groups, and this is one of the limitations of the analysis presented here.

6 RTF foundation statement, see www.righttofoodcampaign.in/about/ foundation-statement.

7 See newspaper pieces at www.righttofoodcampaign.in/food-act/ articles.

8 See www.righttofoodcampaign.in/events.

9 The Fifth Schedule states that all scheduled areas of the country which are forest reserves and inhabited by scheduled tribes are to be administered by the governors of the states by appointing tribal advisory councils with tribal representatives from the relevant forest reserve or scheduled area. The Ninth Schedule of the Constitution dealt with the fact that cultivable land which over thousands of years had come under the ownership of upper castes should be acquired by the government and redistributed among India's landless peasantry.

10 The latter is banned and operates underground, though it has 'open fronts' which continue to function.

11 https://odishapolice.gov.in/?q=node/69.

12 The argument is based on a close reading of a report commissioned by the Planning Commission (2008).

13 The RTF campaign itself is not funded by any national or international organisation. See www.righttofoodcampaign.in/about/ finance.

14 Phone interview conducted with interviewee JB, 28 October 2017.

15 Interview conducted with interviewee FJ, 15 September 2017, New Delhi.

16 Interview conducted with interviewee FJ, 15 September 2017, New Delhi.

17 Phone interview conducted with interviewee JB, 28 October 2017. 18 Phone interview conducted with interviewee PK, 12 September 2017. 19 Phone interview conducted with interviewee PK, 12 September 2017. 20 Phone interview conducted with interviewee AJ, 7 January 2018. 21 Phone interview conducted with interviewee AJ, 7 January 2018. 22 Phone interview conducted with interviewee PK, 12 September 2017. 23 Interview conducted with interviewee FJ, 15 September 2017, New Delhi. 
24 Phone interview conducted with interviewee AJ, 7 January 2018. 25 Written interview conducted with interviewee CT, 16 November 2017. 26 Phone interview conducted with interviewee AJ, 7 January 2018. 27 Interview conducted with interviewee FJ, 15 September 2017, New Delhi.

28 Interview conducted with interviewee FJ, 15 September 2017, New Delhi.

29 Phone interview conducted with interviewee SD, 2 November 2017. 30 Phone interview conducted with interviewee PK, 12 September 2017. 31 Phone interview conducted with interviewee PK, 12 September 2017. 32 Interview conducted with interviewee FJ, 15 September 2017, New Delhi.

33 Phone interview conducted with interviewee PK, 12 September 2017. 34 Phone interview conducted with interviewee PK, 12 September 2017. 35 Phone interview conducted with interviewee JB, 28 October 2017. 36 Phone interview conducted with interviewee SD, 2 November 2017. 37 For example, in the 2004 convention in Bhopal, Jean Drèze noted, 'Land rights is another issue on which a strong need was felt for coordinated action. Various proposals were made at the workshop on "land rights and food sovereignty" and concrete decisions on this are likely to be taken quite soon at follow-up gatherings'. See https://frontline.thehindu.com/static/html/fl2114/ stories/20040716006012500.htm. Yet these have not featured prominently in RTF campaign demands.

38 Phone interview conducted with interviewee JB, 28 October 2017. 39 Phone interview conducted with interviewee SD, 2 November 2017. 40 Phone interview conducted with interviewee AJ, 7 January 2018. 41 Phone interview conducted with interviewee JB, 28 October 2017. 42 Phone interview conducted with interviewee PK, 12 September 2017. 43 Displacement figures estimate more than 50,000 people across three states of Gujarat, Madhya Pradesh, and Maharashtra, www.narmada.org/sardar-sarovar/sc.ruling/Displacement.rehab.html. 44 Phone interview conducted with interviewee AJ, 7 January 2018.

\section{References}

Baviskar, A. (2010) 'Winning the Right to Information in India: Is Knowledge Power?', in J. Gaventa and R. McGee (eds), Citizen Action and National Policy Reform: Making Change Happen, London and New York NY: Zed Books

Baviskar, A. (1997) 'Tribal Politics and Discourses of Environmentalism', Contributions to Indian Sociology 31.2: 195-223

Baviskar, A. (1995) In the Belly of the River: Tribal Conflicts over Development in the Narmada Valley, New Delhi: Oxford University Press

Bhatia, B. (2005) 'The Naxalite Movement in Central Bihar', Economic and Political Weekly 40.15: 1536-49

Birchfield, L. and Corsi, J. (2010) 'Between Starvation and Globalization: Realizing the Right to Food in India', Michigan fournal of International Law 31.4: 691-764 
Chandhoke, N. (2017) 'The Big Squeeze on Civil Society: On the Right to Freedom of Expression', The Hindu, 20 July

Chandra, U. (2013) 'Beyond Subalternity: Land, Community, and the State in Contemporary Jharkhand', Contemporary South Asia 21.1: 52-61

De, R. (2018) A People's Constitution: The Everyday Life of Law in the Indian Republic, Princeton NJ and Oxford: Princeton University Press

Dwivedi, R. (1998) 'Resisting Dams and "Development": Contemporary Significance of the Campaign against the Narmada Projects in India', European Fournal of Development Research 10.2: 135-83

Dwivedi, R. (1997) People's Movements in Environmental Politics: A Critical Analysis of the Narmada Bachao Andolan in India, ISS Working Paper 242, The Hague, The Netherlands: Institute of Social Studies

Giri, S. (2009) 'The Maoist "Problem" and the Democratic Left in India', fournal of Contemporary Asia 39.3: 463-74

Hertel, S. (2015) 'Hungry for Justice: Social Mobilization on the Right to Food in India', Development and Change 46.1: 72-94

Hunt, A. (1993) Explorations in Law and Society: Toward a Constitutive Theory of Law, New York NY: Routledge

Isserman, M. (1987) If I Had a Hammer: The Death of the Old Left and the Birth of the New Left, New York NY: Basic Books

Jenkins, R. and Goetz, A.M. (1999) 'Accounts and Accountability: Theoretical Implications of the Right-to-Information Movement in India', Third World Quarterly 20.3: 603-22

Joshi, A. (2010) 'Do Rights Work? Law, Activism and the Employment Guarantee Scheme', World Development 38.4: 620-30

Krishnan, P. and Subramaniam, M. (2014) 'Understanding the State: Right to Food Campaign in India', The Global South 8.2: 101-18

Langford, M.; Rodríguez-Garavito, C. and Rossi, J. (eds) (2017) Social Rights Fudgments and the Politics of Compliance: Making it Stick, Cambridge: Cambridge University Press

McCann, M.W. (1994) Rights at Work: Pay Equity Reform and the Politics of Legal Mobilization, Chicago IL: University of Chicago Press

Morris, A.D. (1984) The Origins of the Civil Rights Movement: Black Communities Organizing for Change, New York NY: The Free Press

Pande, S. (2014) 'The Right to Know, the Right to Live: Grassroots Struggle for Information and Work in India', Doctoral thesis (PhD), Development Studies, University of Sussex

Pande, S. and Houtzager, P.P. (2016) Civil Society Innovation and Resilience in the Struggle for the Right to Food in India, IDS Working Paper 475, Brighton: IDS

Planning Commission (2008) Development Challenges in Extremists Affected Areas: Report of An Expert Group, New Delhi: Government of India, http://planningcommission.nic.in/reports/publications/rep_dce.pdf (accessed 20 August 2019)

Prasad, A. (2010) 'The Political Economy of "Maoist Violence" in Chhattisgarh', Social Scientist 38.3-4: 3-24

Raina, V. (2004) 'Political Diversity, Common Purpose: Social Movements in India', Inter-Asia Cultural Studies 5.2: 320-27 
Ramana, P.V. (ed.) (2008) The Naxal Challenge: Causes, Linkages and Policy Options, Delhi: Pearson Education India

Shah, A. (2011) 'Alcoholics Anonymous: The Maoist Movement in Jharkhand, India', Modern Asian Studies 45.5: 1095-117

Shah, A. (2006) 'Markets of Protection: The "Terrorist" Maoist Movement and the State in Jharkhand, India', Critique of Anthropology 26.3: 297-314

Sharp, J.P.; Routledge, P.; Philo, C. and Paddison, R. (eds) (2000) Entanglements of Power: Geographies of Domination/Resistance, London and New York NY: Routledge

Singh, S. (2010) 'The Genesis and Evolution of the Right to Information Regime in India', paper for Regional Workshop 'Towards More Open and Transparent Governance in South Asia', New Delhi, 27-29 April

Sinha, D.; Patnaik, B.; Raaj, V.; Bhattacharya, S. and Joshi, A. (2014) Popular Actions, State Reactions: The Moral and Political Economy of Food in India, Brighton: IDS

Srinivasan, V. and Narayanan, S. (2007) 'Food Policy and Social Movements: Reflections on the Right to Food Campaign in India', in P. Pinstrup-Andersen and D.D. Watson II (eds), Food Policy for Developing Countries, Ithaca NY: Cornell University

Thivet, D. (2014) 'A Nation Without Hunger? Threats to Food Security in Contemporary India', in J. Miklian and Å. Kolås (eds), India's Human Security: Lost Debates, Forgotten People, Intractable Challenges, London: Routledge

Tilly, C. (1978) From Mobilization to Revolution, New York NY: Random House

Whittier, N. (1997) 'Political Generations, Micro-Cohorts, and the Transformation of Social Movements', American Sociological Review 62.5: $760-78$

Whittier. N. (1995) Feminist Generations: The Persistence of the Radical Women's Movement, Philadelphia PA: Temple University Press 
